\title{
Injustices made right: Ed Scott Jr.'s victory in saving the family farm
}

\author{
Review by Aaryn Wilson * \\ St. Paul, Minnesota
}

Review of Catfish D ream: E d Soott's Fight for his F amily F arm and Racial Justio in the Mississippi D elta, by Julian Rankin. (2018). University of G eorgia Press, A thens, GA. Available as hardcover, paperback, and ebook; 160 pages. Publisher's website:

http:// www.ugapress.org/ index.php/ books/ catfish dream/

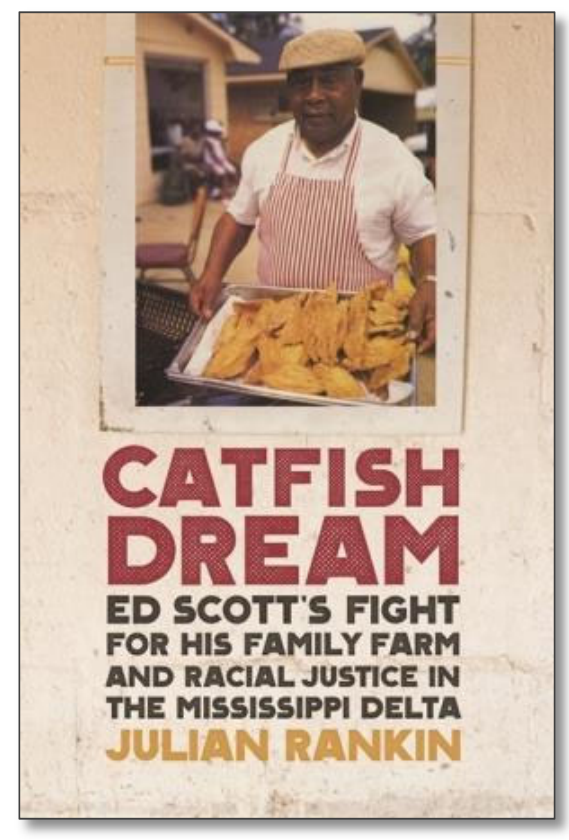

Submitted September 13, 2018 / Published online November 15, 2018

Citation: Wilson, A. (2018). Injustices made right: Ed Scott Jr.'s victory in saving the family farm [Book review]. Journal of A griculture, F ood Systems, and C ommunity D evelopment, 8(3), 229-230. https:/ / doi.org/ 10.5304/ jafscd.2018.083.018

Copyright @ 2018 by the Author. Published by the Lyson Center for Civic Agriculture and Food Systems. Open access under CC BY license.

C atfish $D$ ream is told in 129 pages with every line crafted to tell the best parts of a man who rose above barriers to become a war hero, community hero, family hero, and business hero. In this book, Rankin articulates the proud history of the Scott family in farming, community, and business. The book traces Ed Scott Jr.'s struggles to keep his land, despite the discrimination and disenfranchisement he and other African American farmers faced during the $20^{\text {th }}$ century, and on the

\footnotetext{
* Aaryn Wilson received his BS in Plant Science from the University of Minnesota, Twin Cities. He has worked for nonprofits planting community gardens in food deserts, in a soil research lab, at urban farms, and is currently with AmeriCorps through the Minnesota Pollution Control Agency. He can be reached at Aarynj1@ yahoo.com.
}

slow road to seeing injustices made right.

Instead of being a book that just makes readers angry and sad about the plight of African American farmers in the recent past, Rankin describes Ed Scott Jr. as a figure not unlike Henry Ford. A strength of this book is that it is approachable to all, and everyone who reads it will be glad they did. This book could appeal to both academics and practitioners.

The book is divided up into three sections. Part one, "Seed," describes Ed Scott Jr.'s father as a man who feared no white man and acquired land from white landowners at a time when many blacks were sharecroppers. "Edward Sr. taught his son that a bounty of work was the real blessing, and a moral businessman was one who shared the fruits of his enterprise" (p. 36). Therefore the seed not 
just for farming, but for economic self-reliance, was inherited from his father. Like a seed that can last indefinitely if cared for properly, that land Ed Scott Jr. inherited was given to him with the understanding that he would pass it along to his children.

In part two, "Stalk," Rankin weaves Ed Scott Jr.'s life with the changing times he and other black farmers faced in the period from about 1960 to 1970. Additionally, Rankin highlights how Scott worked alongside people like Fannie Lou Hammer and Dr. T. R. M Howard, all of whom worked to grow black power in the D elta through business, politics, spirituality, and education. Scott is portrayed as a stubborn farmer who saved his family farm by following in the footsteps of white farmers who turned to catfish farming when row cropping ceased to be profitable. He marched on, creating a catfish enterprise out of thin air when the government and catfish farming cooperatives did all they could to crush him.

Like his father, Scott made his children and grandchildren work on the farm. In part three, "Reap," Rankin describes Scott as a powerful man who motivated all of his employees and family to work as hard as they could. D aniel, Ed Scott Jr.'s grandson, said, "I was seeing things that the average person would be way up in life before they got the chance to experience" (p. 88). For many of Ed Scott Jr.'s employees, the jobs were a means out of the misery of unemployment.

Reap traces the process of how Ed Scott Jr. lost his catfish business and land in the 1990s until 2011, when the courts settled in his favor, awarding him over a million dollars in the Pigford v. G lick man class-action lawsuit. Instead of going out and spending the money willy-nilly, with the help of his daughter he was able to buy back his land from the very governmental entity responsible for taking it in the first place.

Catfish D ream is a wonderfully written story about a rare African American farmer who persevered through adversity and was able to create a legacy that will forever be remembered through this book and several other archives. Perhaps one weakness of the book is that Rankin left out information about the minority land ownership discrimination that is continuing to occur. For example, a Kansas farmer by the name of Carlos Valencia has been facing discrimination for the past several years as he attempts to create an organic poultry enterprise (Webster, 2018). Ed Scott Jr. will now sit alongside the "Peanut Man" G eorge Washington Carver - when I think of African American farming heroes.

\section{Reference}

Webster, B. (2018). Farmer's problems in rural Kansas smack of racial discrimination. O rganic Broadcaster, 26(4), pp. 9, 14. Retrieved from https:/ / mosesorganic.org/ farmer-racial-discrimination/ 